\title{
Fibrous feedstuffs for the nitrogen retention of growing pigs
}

\author{
Leonardo Tombesi da Rocha ${ }^{1}$ iD Josué Sebastiany Kunzler ${ }^{1}$ (iD Marcos Speroni Ceron $^{2 *}$ (iD) \\ Carlos Augusto Rigon Rossi ${ }^{3}$ iD Arlei Rodrigues Bonet de Quadros ${ }^{1}$ iD Vladimir de Oliveira ${ }^{1}$
}

${ }^{1}$ Departamento de Zootecnia, Universidade Federal de Santa Maria (UFSM), Santa Maria, RS, Brasil.

2Departamento de Agronomia, Universidade José do Rosário Vellano (UNIFENAS), 37132440, Alfenas, MG, Brasil. E-mail: marcossperoni@gmail.com. ${ }^{*}$ Corresponding author.

${ }^{3}$ Departamento de Clínica de Grandes Animais, Universidade Federal de Santa Maria (UFSM), Santa Maria, RS, Brasil.

ABSTRACT: The aim of this study was to measure the nitrogen ( $N$ ) balance of pigs fed with lysine-limiting diets containing practical levels of wheat bran $(W B)$ or soybean hulls (SH). Twelve pigs with average weights of $57.36 \pm 2.01$ and $72.68 \pm 3.24 \mathrm{~kg}$ were used in trials 1 and 2 , respectively. In trial 1, treatments were CT1 - control diet and WB - diet with inclusion of $15 \% \mathrm{WB}$. In trial 2, CT2 - control diet and SHdiet with inclusion of $6 \% \mathrm{SH}$. Fibrous diets increased $(P<0.05)$ the fecal $N$ in 63.54 and $60.55 \%$ in relation to CT1 and CT2, respectively. The urinary $N$ was higher $(P<0.05)$ in pigs receiving the $W B$ diet, but was not influenced in the trial with $S H$. The $N$ retention $(N R E T)$ was higher $(P>0.05)$ in pigs ingesting the WB diet; although, when the proportion of NRET was expressed relative to $N$ ingested (NING) there was no difference $(P>0.05)$ between treatments. Inclusion of $S H$ did not affect $(P>0.05)$ the NRET when the result was expressed in absolute or proportional terms. In conclusion, inclusion of practical levels of WB and SH does not significantly affect the metabolic costs involved with nitrogen metabolism. However, only $W B$ was able to contribute to the $N$ balance of pigs, while the relative amount of $N$ added by SH was fully recovered in feces.

Key words: soybean hulls, wheat bran, urinary nitrogen, fecal nitrogen.

Contribuição dos alimentos fibrosos para a retenção de nitrogênio de suínos em crescimento

RESUMO: O objetivo deste estudo foi medir o balanço de nitrogênio ( $N$ ) de suínos alimentados com dietas limitantes em lisina contendo níveis práticos de inclusão de farelo de trigo (FT) ou casca de soja (CS). Foram utilizados 24 suínos machos castrados com peso médio inicial

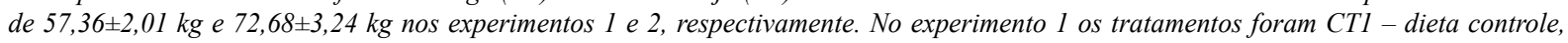
e FT-dieta com inclusão de $15 \%$ de FT. No experimento 2 CT2 - dieta controle, e CS - dieta com inclusão de 6\% CS. As dietas fibrosas aumentaram $(P<0,05)$ o $N$ fecal em 64,54 e 60,55\% em relação a CT1 e CT2, respectivamente. O N urinário foi maior $(P<0,05)$ nos suínos que receberam a dieta FT, mas não foi afetado no experimento com $C S$. A retenção de $N(N R E T)$ foi maior $(P<0,05)$ nos suínos alimentados com a dieta FT, entretanto quando a proporção do NRET foi expressa em relação ao $N$ ingerido (NING) não houve diferença entre os tratamentos $(P<0,05)$. A inclusão de CS não afetou $(P<0,05)$ a NRET quando os resultados foram expressos em termos absolutos ou proporcionais. Em conclusão, a inclusão de niveis práticos de FT ou CS não afeta significativamente o custo metabólico envolvido no metabolismo de $N$. Entretanto, apenas o FT foi capaz de contribuir para o balanço de $N$ dos suínos, enquanto a quantidade $N$ relativa a adição de CS foi totalmente recuperada nas fezes.

Palavras-chave: casca de soja, farelo de trigo, nitrogênio fecal, nitrogênio urinário.

\section{INTRODUCTION}

The use of by products in diets for pigs can be an alternative to reduce feeding costs and to contribute to pig farming sustainability. The fiber content of many feedstuffs may cause alterations in digestion and utilization of dietary nutrients. In general, the digestibility of neutral detergent fiber (NDF) is variable and dependent on its origin (LE GOFF \& NOBLET, 2002). Even so, the effective contribution of NDF to the energy balance, for example, can be eventually considered null, because it increases endogenous losses and reduces the digestibility of other dietary nutrients (LIBAOMERCADO et al., 2006; NOBLET, 2007; METZLER \& MOSENTHIN, 2008; BLANK et al., 2012).

Fibrous feedstuffs also contribute with amino acids (AA) to meet the maintenance and production requirements of pigs (NRC, 2012). The amount and digestibility of AA varies according to the ingredient; although, the presence of fiber may reduce the AA digestion and absorption (LIBAO- 
MERCADO et al., 2006). In addition, fiber induces an increase in specific endogenous losses, which may constitute a source of inefficiency in AA utilization (LIU et al., 2016).

Wheat bran (WB) and soybean hulls (SH) are among the main fibrous by products used in pig farming. Considering practical inclusion levels, in a corn and soybean meal based diet, WB and $\mathrm{SH}$ can contribute 16 and $5 \%$ of the ideal protein, respectively (ROSTAGNO et al., 2011). However, if we consider the metabolic cost to synthesize endogenous proteins lost due to the presence of fiber, the contribution of these feedstuffs for nitrogen retention may be small or even null.

To test this hypothesis, a study was planned with the aim of measuring the nitrogen balance of pigs fed with lysine-limited diets containing practical levels of $\mathrm{WB}$ or $\mathrm{SH}$. The assumption was that the inclusion of these feedstuffs at practical levels would influence $\mathrm{N}$ utilization. Pigs fed with these diets would have lower retention efficiency of the digestible nitrogen ingested, which would represent indirect evidence of the need to evaluate in greater depth the contribution of fibrous feedstuffs to the nitrogen balance of pigs.

\section{MATERIALS AND METHODS}

Twelve castrated pigs from a commercial line with average weight of $57.36 \pm 2.01$ were used in trial 1. For trial 2, another 12 pigs weighing $72.68 \pm 3.24 \mathrm{~kg}$ were used. The animals were housed individually in metabolic cages for 15 days, with 10 days for adaptation (3 days in collective pens and 7 days in cages) and 5 days for total collection of feces and urine. Cages were kept in a room with a temperature range of $22 \pm 3{ }^{\circ} \mathrm{C}$.

The animals were divided into two trials in a completely randomized design. In trial 1, the animals were fed with two experimental diets: CT1 - control diet and WB - diet with inclusion of $15 \% \mathrm{WB}$ (Table 1). In trial 2, the two diets were as follows: CT2 - control diet and $\mathrm{SH}-$ diet with inclusion of $6 \% \mathrm{SH}$. In each group, control diets were formulated to supply $85 \%$ of the calculated standardized lysine requirements, while the energy and other nutrients were included to meet the recommendations of ROSTAGNO et al. (2011).

The experimental diets were prepared by replacing starch with $15 \% \mathrm{WB}$ or $6 \% \mathrm{SH}$ in trials 1 and 2 , respectively. These inclusion rates were adopted because they are considered acceptable levels in practical diets (ROSTAGNO et al., 2011). Soybean oil was added to maintain the diets with the same net energy.

The animals received four meals $(8: 00$, $11: 30,14: 00$ and 17:30 h) in the amounts of 90 and $95 \mathrm{~g} \mathrm{~kg}^{-1}$ of metabolic body weight $\left(\mathrm{BW}^{0.75}\right)$ per day in trials 1 and 2, respectively. Daily feed refusals were collected, dried, weighed and discounted from the total amounts provided. In the intervals between meals, animals had free access to water.

The collected urine was stored in dark amber glass containers containing $30 \mathrm{~mL}$ of sulfuric acid $\left(\mathrm{H}_{2} \mathrm{SO}_{4}\right)$ to prevent bacterial contamination and $\mathrm{N}$ volatilization. Twice daily, the containers were emptied and the total volume of urine was recorded. At this time, the $\mathrm{pH}$ was checked and if necessary adjusted with $\mathrm{H}_{2} \mathrm{SO}_{4}$ for the sample to be stored at a $\mathrm{pH}$ below 2 .

Feces were collected according to the marker-to-marker approach using ferric oxide (1\%) as a marker. Feces was collected twice daily, placed in plastic bags and kept in a freezer at $-18^{\circ} \mathrm{C}$. At the end of each period, the feces was thawed and homogenized, and an aliquot was removed for drying at $65{ }^{\circ} \mathrm{C}$ in a forced-air oven before being milled for chemical analysis.

Analyses of dry matter (DM, method 930.15), mineral matter (MM, method 942.05) and $\mathrm{N}$ (988.05 method) of feed ingredients, and of feces and urine were performed following the methodologies of the Association of Official Analytical Chemists (AOAC, 1995). To determine the NDF and acid detergent fiber (ADF) of diets and ingredients, the VAN SOEST et al. (1967) methodology was used. Hemicellulose was estimated by difference (NDF - ADF). The AA composition of feeds were also analyzed (method $982.30 \mathrm{E}[\mathrm{a}, \mathrm{b}, \mathrm{c}]$ ) (AOAC, 1995). Standardized AA content were calculated by multiplying the analyzed amino acid content by standardized digestibility coefficient of SAUVANT et al. (2004).

The ratios fecal: ingested (NFEC:NING), absorbed/ingested (NABS:NING), urinary: ingested (NURI:NING) and retained: ingested (NRET:NING) were calculated to quantify, in $g$ g-1, the proportion of ingested $\mathrm{N}$ destined to feces, absorbed, excreted in urine or retained, respectively. Likewise, the ratios: urinary: absorbed (NURI:NABS), and retained: absorbed (NRET:NABS), were used to determine how much of the absorbed $\mathrm{N}$ were excreted or retained by pigs. 
Table 1 - Ingredient composition and nutrient content, as feed basis, of experimental diets of the trial 1 and 2.

\begin{tabular}{|c|c|c|c|c|}
\hline \multirow[t]{2}{*}{ Ingredients $\left(\mathrm{g} \mathrm{kg}^{-1}\right)$} & \multicolumn{2}{|c|}{ 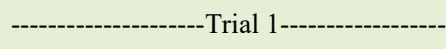 } & \multicolumn{2}{|c|}{ 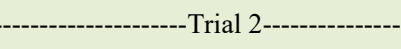 } \\
\hline & Control 1 & Wheat Bran & Control 2 & Soybean hulls \\
\hline Maize & 623.96 & 623.96 & 743.40 & 743.40 \\
\hline Soybean meal & 147.81 & 147.81 & 127.80 & 127.80 \\
\hline Starch & 200.00 & 8.85 & 90.00 & 5.00 \\
\hline Wheat bran & - & 150.00 & - & - \\
\hline Soybean hulls & - & - & - & 60.00 \\
\hline Soya oil & 3.85 & 45.00 & 10.00 & 35.00 \\
\hline Limestone & 5.44 & 5.44 & 5.70 & 5.70 \\
\hline Bicalcium phosphate & 9.76 & 9.76 & 13.50 & 13.50 \\
\hline Salt & 4.25 & 4.25 & 4.50 & 4.50 \\
\hline L-lysine & 1.67 & 1.67 & 2.00 & 2.00 \\
\hline DL-methionine & 0.24 & 0.24 & 0.10 & 0.10 \\
\hline L-threonine & 0.02 & 0.02 & - & - \\
\hline Mineral premix ${ }^{1}$ & 1.50 & 1.50 & 1.50 & 1.50 \\
\hline Vitamin premix $^{1}$ & 1.50 & 1.50 & 1.50 & 1.50 \\
\hline Total & 1000 & 1000 & 1000 & 1000 \\
\hline \multicolumn{5}{|c|}{ 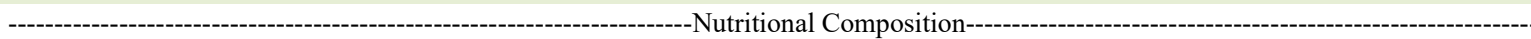 } \\
\hline Dry matter ${ }^{*}\left(\mathrm{~g} \mathrm{~kg}^{-1}\right)$ & 860.60 & 874.70 & 873.60 & 883.90 \\
\hline $\operatorname{Protein}^{*}\left(\mathrm{~g} \mathrm{~kg}^{-1}\right)$ & 124.36 & 142.75 & 117.50 & 124.90 \\
\hline Ether extract ${ }^{2}\left(\mathrm{~g} \mathrm{~kg}^{-1}\right)$ & 40.9 & 73.9 & 37.9 & 85.9 \\
\hline Metabolizable energy ${ }^{2}\left(\mathrm{kcal} \mathrm{kg}^{-1}\right)$ & 3300 & 3322 & 3298 & 3336 \\
\hline Net energy ${ }^{2}\left(\mathrm{kcal} \mathrm{kg}^{-1}\right)$ & 2568 & 2576 & 2569 & 2577 \\
\hline Neutral detergent fiber ${ }^{*}\left(\mathrm{~g} \mathrm{~kg}^{-1}\right)$ & 87.40 & 143.10 & 99.82 & 137.75 \\
\hline Acid detergent fiber ${ }^{*}\left(\mathrm{~g} \mathrm{~kg}^{-1}\right)$ & 27.21 & 46.60 & 29.83 & 55.23 \\
\hline Total dietary fiber ${ }^{2}\left(\mathrm{~g} \mathrm{~kg}^{-1}\right)$ & 109.00 & 172.70 & 120.60 & 166.50 \\
\hline Soluble fiber ${ }^{2}\left(\mathrm{~g} \mathrm{~kg}^{-1}\right)$ & 14.10 & 20.30 & 15.70 & 19.10 \\
\hline Insoluble fiber ${ }^{2}\left(\mathrm{~g} \mathrm{~kg}^{-1}\right)$ & 94.90 & 152.40 & 104.90 & 147.30 \\
\hline Lysine $^{3}\left(\mathrm{~g} \mathrm{~kg}^{-1}\right)$ & 6.14 & 6.76 & 6.12 & 6.35 \\
\hline Methionine $^{3}\left(\mathrm{~g} \mathrm{~kg}^{-1}\right)$ & 1.97 & 2.23 & 1.89 & 1.94 \\
\hline Methionine + cystine $^{3}\left(\mathrm{~g} \mathrm{~kg}^{-1}\right)$ & 3.69 & 4.31 & 3.72 & 3.83 \\
\hline Threonine $^{3}\left(\mathrm{~g} \mathrm{~kg}^{-1}\right)$ & 4.19 & 4.65 & 4.01 & 4.14 \\
\hline Tryptophan ${ }^{3}\left(\mathrm{~g} \mathrm{~kg}^{-1}\right)$ & 1.20 & 1.46 & 1.15 & 1.20 \\
\hline Calcium $^{2}\left(\mathrm{~g} \mathrm{~kg}^{-1}\right)$ & 5.00 & 5.20 & 6.00 & 6.30 \\
\hline Digestible phosphorus ${ }^{2}\left(\mathrm{~g} \mathrm{~kg}^{-1}\right)$ & 2.50 & 3.20 & 3.10 & 3.10 \\
\hline $\operatorname{Sodium}^{2}\left(\mathrm{~g} \mathrm{~kg}^{-1}\right)$ & 1.70 & 1.70 & 1.80 & 1.80 \\
\hline
\end{tabular}

*Analyzed values. ${ }^{1}$ Amount $/ \mathrm{kg}$ of vitamin and mineral premix: retinyl acetate, 13,500.000 IU; cholecalciferol, $1.950,000$ IU; DL- $\alpha$ tocopheryl acetate, $85.000 \mathrm{IU}$; menadione, $2,450 \mathrm{mg}$; thiamine, $950 \mathrm{mg}$; riboflavin, 4,000 mg; pyridoxine, 2,400 mg; cyanocobalamin, 29,000 mcg; niacin, $24 \mathrm{~g}$; pantothenic acid, 9,500 mg; D-biotin, $95 \mathrm{mg}$; folic acid 1,450 mg; Fe (ferrous sulfate), $100 \mathrm{~g}$; Cu (copper sulfate), $15 \mathrm{~g}$; Zn (zinc sulfate), $150 \mathrm{~g}$; Mn (manganese oxide), $70 \mathrm{~g}$; Se (sodium selenite), $450 \mathrm{mg}$; I (potassium iodate), $1.400 \mathrm{mg}$; ${ }^{2}$ Calculated values (ROSTAGNO et al, 2011; HUANG et al, 2015; PASCOAL et al, 2015); ${ }^{4}$ Obtained by multiplying the analyzed amino acid content by standardized digestibility coefficient of SAUVANT et al. (2004).

All variables were subjected to analysis of variance according to a completely randomized design using the effects of treatments in the model. The experimental unit was a pig, and the Tukey test with an alpha level of 0.05 was used to test the statistical differences between means. All statistical analyses were performed using the statistical program MINITAB (2013).

\section{RESULTS}

Trial 1 - wheat bran

The DMI was not different $(\mathrm{P}>0.05)$ between treatments. The fiber intake, regardless of the technique used in quantification was higher $(\mathrm{P}<0.01)$ in the diets with the addition of the fiber source. The ether extract intake was $84 \%$ higher $(\mathrm{P}<0.01)$ in diets 
with inclusion of WB. Amounts of feces and DM excreted were 79 and $52 \%$ higher $(\mathrm{P}<0.01)$ in the WB diet than in the CT1 diet.

The $\mathrm{N}$ ingested (NING) was approximately $15 \%$ higher $(\mathrm{P}<0.01)$ in the diet with WB (Table 2). Pigs fed with the WB diet excreted about $43 \%$ more fecal N (NFEC) $(\mathrm{P}<0.01)$. The NFEC represented 8.7 and $10.9 \%$ of the NING in the CT1 and WB treatments, respectively (Figure 1). Pigs fed with the WB diet absorbed $4.5 \mathrm{~g} \mathrm{~d}^{-1}$ of more $\mathrm{N}$ than those fed with CT1; although, in proportional terms (percent of NING) there was a decrease of $2 \%$ of absorbed $\mathrm{N}$ (NABS) in the animals of the WB treatment.

The amount of urinary $\mathrm{N}$ (NURI) was approximately $10 \%$ higher $(\mathrm{P}<0.04)$ in the animals fed with the diet with WB compared to those fed the CT1 diet. When the NURI was expressed as a proportion of NING (Figure 1), no differences were reported ( $P>0.05$ ) between treatments (41 and 39\% in the WB and CT1 groups, respectively). The N retention (NRET) was higher by $15 \%$ in the pigs ingesting WB diet; although, NRET:NING (50\%) and NRET:NABS $(55.5 \%)$ were similar $(\mathrm{P}>0.05)$ between treatments.
Trial 2 - soybean hulls

The DMI was not different $(\mathrm{P}>0.05)$ between treatments (Table 3 ). The DM excreted was $30 \%$ higher $(\mathrm{P}<0.02)$ in pigs fed with the $\mathrm{SH}$ diet compared with those fed with CT2. The fiber intake, regardless of the technique used for quantification, was higher $(\mathrm{P}<0.01)$ in diets with inclusion of fiber source. The ether extract intake was higher by $23 \%(\mathrm{P}<0.01)$ in the diet with inclusion of SH compared to CT2.

The SH diet provided a higher NING of $2.7 \mathrm{~g} \mathrm{~d}^{-1}(\mathrm{P}<0.01)$, which represents an approximate $10 \%$ increase, compared to CT2. The NFEC of pigs fed with the SH diet was $65 \%$ higher $(\mathrm{P}<0.01)$ than that of pigs fed with the CT2 diet (4.39 vs. 7.25 $\mathrm{g} \mathrm{d}^{-1}$, respectively). Thus, there was no difference $(\mathrm{P}>0.05)$ between the amount of NABS among treatments, but the NABS:NING was lower $(\mathrm{P}<0.01)$ in the animals fed with the SH diet. The NURI expressed in absolute terms $\left(\mathrm{g} \mathrm{d}^{-1}\right)$ or expressed as the proportion of NING or NABS did not change $(\mathrm{P}>0.05)$ with the inclusion of $\mathrm{SH}$ in the diet. The inclusion of SH also had no effect $(\mathrm{P}>0.05)$

Table 2 - Effects of fiber intake on dry matter and nitrogen balance of growing pigs (Trial 1).

\begin{tabular}{|c|c|c|c|c|c|}
\hline \multirow[t]{2}{*}{ Variables } & \multicolumn{5}{|c|}{ 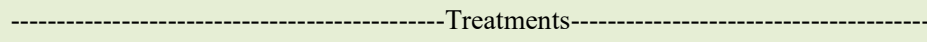 } \\
\hline & Control 1 & WB & SEM & $\mathrm{CV}, \%$ & PROB \\
\hline Replicates & 6 & 6 & - & - & - \\
\hline Initial body weight (kg) & 57.20 & 57.52 & 0.86 & 3.67 & 0.80 \\
\hline Dry matter intake $\left(\mathrm{g} \mathrm{d}^{-1}\right)$ & 1700.30 & 1735.40 & 19.30 & 2.76 & 0.23 \\
\hline NDF intake $\left(\mathrm{g} \mathrm{d}^{-1}\right)$ & 172.68 & 283.91 & 2.51 & 2.69 & 0.00 \\
\hline Hemicellulose intake $\left(\mathrm{g} \mathrm{d}^{-1}\right)$ & 115.62 & 160.70 & 1.52 & 2.69 & 0.00 \\
\hline Soluble fiber intake $\left(\mathrm{g} \mathrm{d}^{-1}\right)$ & 27.95 & 40.30 & 0.37 & 2.69 & 0.00 \\
\hline Insoluble fiber intake $\left(\mathrm{g} \mathrm{d}^{-1}\right)$ & 187.53 & 302.39 & 2.69 & 2.69 & 0.00 \\
\hline Ether extract intake $\left(\mathrm{g} \mathrm{d}^{-1}\right)$ & 69.71 & 128.23 & 1.09 & 2.70 & 0.00 \\
\hline Excreted feces $\left(\mathrm{g} \mathrm{d}^{-1}\right)$ & 386.58 & 693.16 & 25.50 & 10.81 & 0.00 \\
\hline Dry matter excreted $\left(\mathrm{g} \mathrm{d}^{-1}\right)$ & 139.60 & 212.91 & 7.67 & 10.67 & 0.00 \\
\hline \multicolumn{6}{|c|}{ 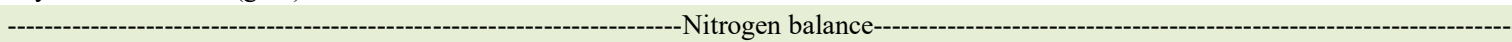 } \\
\hline Ingested $\left(\mathrm{g} \mathrm{d}^{-1}\right)$ & 39.31 & 45.30 & 0.47 & 2.71 & 0.00 \\
\hline Fecal $\left(\mathrm{g} \mathrm{d}^{-1}\right)$ & 3.45 & 5.43 & 0.18 & 9.86 & 0.00 \\
\hline Fecal/Ingested $\left(\mathrm{g} \mathrm{g}^{-1}\right)$ & 0.09 & 0.11 & 0.00 & 9.47 & 0.00 \\
\hline Absorbed $\left(\mathrm{g} \mathrm{d}^{-1}\right)$ & 35.86 & 39.88 & 0.46 & 2.97 & 0.00 \\
\hline Absorbed/ingested $\left(\mathrm{g} \mathrm{g}^{-1}\right)$ & 0.91 & 0.88 & 0.00 & 0.01 & 0.00 \\
\hline Urinary $\left(\mathrm{g} \mathrm{d}^{-1}\right)$ & 16.14 & 17.69 & 0.46 & 6.67 & 0.04 \\
\hline Urinary/ingested $\left(\mathrm{g} \mathrm{g}^{-1}\right)$ & 0.41 & 0.39 & 0.01 & 0.05 & 0.13 \\
\hline Urinary/absorbed $\left(\mathrm{g} \mathrm{g}^{-1}\right)$ & 0.45 & 0.44 & 0.01 & 5.58 & 0.67 \\
\hline Retained $\left(\mathrm{g} \mathrm{d}^{-1}\right)$ & 19.72 & 22.18 & 0.44 & 5.14 & 0.00 \\
\hline Retained/ingested $\left(\mathrm{g} \mathrm{g}^{-1}\right)$ & 0.50 & 0.49 & 0.01 & 5.05 & 0.94 \\
\hline Retained/absorbed $\left(\mathrm{g} \mathrm{g}^{-1}\right)$ & 0.55 & 0.56 & 0.01 & 4.52 & 0.67 \\
\hline
\end{tabular}

WB, diet with $15 \%$ of wheat bran inclusion; SEM, Standard error of means; CV, Coefficient of variation; PROB, Probability; NDF, Neutral detergent fiber. 


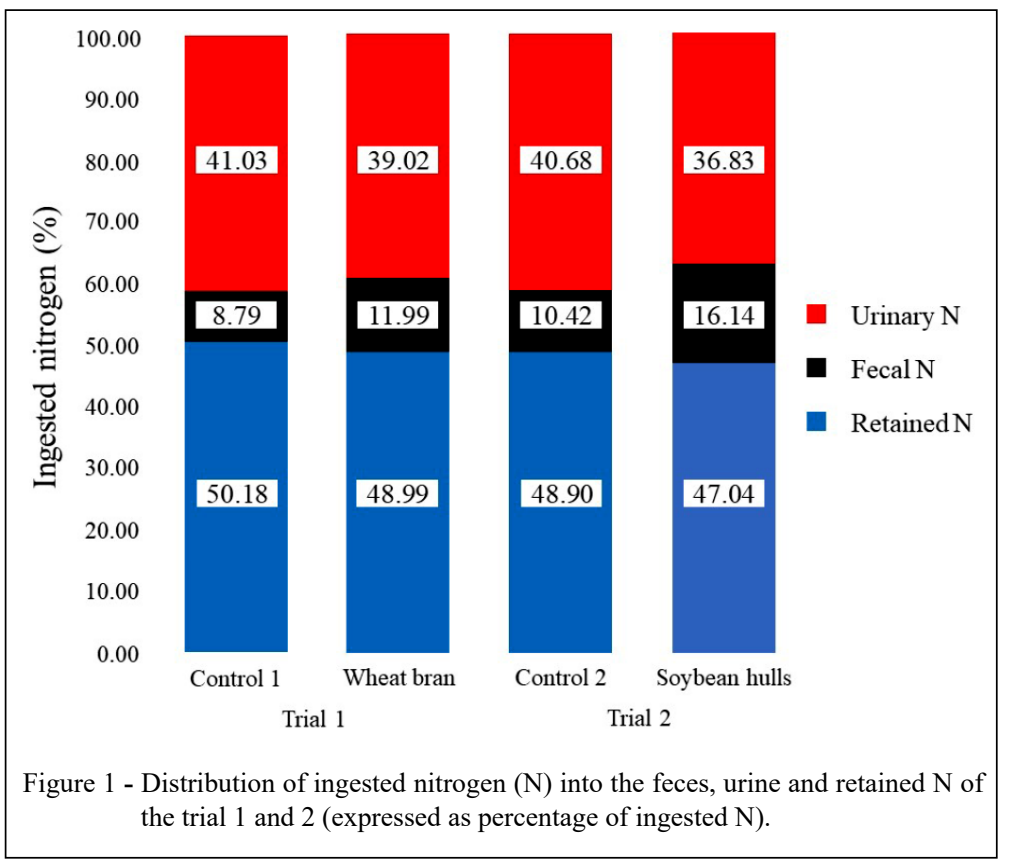

on NRET when the result was expressed in either absolute $\left(\mathrm{g} \mathrm{d}^{-1}\right)$ or proportional terms. On average, NRET:NING and NRET:NABS represented 48 and $55.5 \%$ for the CT2 and SH diets, respectively.

\section{DISCUSSION}

\section{Trial 1 - wheat bran}

As expected, the DMI was not different between treatments. The increase in fiber intake was a consequence of WB addition, which has high levels of this component (HUANG et al., 2015). The ether extract intake was influenced by the soybean oil added to obtain isoenergetic diets. The effect of WB on the amount of feces and DM excreted was associated with fiber characteristics, such as water holding capacity and increase in fecal bulk, which may increase feces moisture and the amount of DM excreted (WILFART et al., 2007).

The higher $\mathrm{N}$ intake observed in pigs receiving the WB diet was because fiber source was added to replace starch, which is virtually $\mathrm{N}$-free. Effect of the WB diet on the NFEC was similar to that observed by other authors (ZHANG et al., 2013). Due to higher fiber content, there was an increase in the $\mathrm{N}$ that reaches the large intestine. The $\mathrm{N}$ is used as a substrate for the development and growth of bacterial populations, resulting in increased NFEC (JHA \& BERROCOSO, 2016). Possibly, bacterial growth in association with the increase in intestinal epithelial desquamation and endogenous protein secretion, influenced by the fiber, resulted in higher NFEC:NING ratio of the animals consuming the WB diet. In addition, the presence of $\mathrm{N}$ bound to the NDF in wheat bran is 9 times higher than in soybean meal, for example (ROCHA JR et al., 2002). As this $\mathrm{N}$ is not available for the animal, it will be excreted in feces (BINDELLE et al., 2008).

A large portion of NURI originates from absorbed and unused AA, either because they are above requirements or are unbalanced in relation to the ideal protein profile (NRC, 2012). Fibrous feedstuffs, especially those with high soluble fiber content, such as $\mathrm{WB}$, increase the $\mathrm{N}$ and $\mathrm{AA}$ endogenous losses (BLANK et al., 2012) and thus may cause imbalance in the AA profile.

The NURI:NABS ratio indicated that the addition of WB does not affect the post-absorptive use of $\mathrm{N}$ or AA, a similar result to that observed by HANSEN et al. (2007), who used beet pulp, SH or pectin in diets for growing pigs.

There is a consensus that the standardized ileal digestibility (SID) of AA should be used in the formulation of diets for pigs (STEIN, 2017). In the SID system, the cost associated with the specific losses of $\mathrm{N}$ and AA, caused by the fiber, is attributed to the ingredient. However, the metabolic inefficiency for endogenous protein synthesis is not considered. As the magnitude of these losses may be significant, depending on the type and level of the fiber source 
Table 3 - Effects of fiber intake on dry matter and nitrogen balance of growing pigs (Trial 2).

\begin{tabular}{|c|c|c|c|c|c|}
\hline \multirow[t]{2}{*}{ Variables } & \multicolumn{5}{|c|}{ - } \\
\hline & Control 2 & SH & SEM & $\mathrm{CV}, \%$ & PROB \\
\hline Replicates & 6 & 6 & - & - & - \\
\hline Initial body weight (kg) & 72.62 & 72.75 & 1.78 & 5.98 & 0.96 \\
\hline Dry matter intake $\left(\mathrm{g} \mathrm{d}^{-1}\right)$ & 1955.30 & 1981.00 & 36.20 & 4.50 & 0.62 \\
\hline NDF intake $\left(\mathrm{g} \mathrm{d}^{-1}\right)$ & 223.41 & 308.74 & 4.94 & 4.58 & 0.00 \\
\hline Hemicellulose intake $\left(\mathrm{g} \mathrm{d}^{-1}\right)$ & 156.65 & 184.95 & 3.16 & 4.52 & 0.00 \\
\hline Soluble fiber intake $\left(\mathrm{g} \mathrm{d}^{-1}\right)$ & 35.23 & 42.89 & 0.72 & 4.53 & 0.00 \\
\hline Insoluble fiber intake $\left(\mathrm{g} \mathrm{d}^{-1}\right)$ & 234.81 & 330.19 & 5.29 & 4.58 & 0.00 \\
\hline Ether extract intake $\left(\mathrm{g} \mathrm{d}^{-1}\right)$ & 74.15 & 170.14 & 2.43 & 4.88 & 0.00 \\
\hline Excreted feces $\left(\mathrm{g} \mathrm{d}^{-1}\right)$ & 556.00 & 669.40 & 54.40 & 21.75 & 0.17 \\
\hline Dry matter excreted $\left(\mathrm{g} \mathrm{d}^{-1}\right)$ & 170.70 & 222.00 & 12.80 & 15.94 & 0.02 \\
\hline \multicolumn{6}{|c|}{ 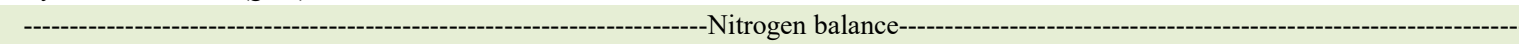 } \\
\hline Ingested $\left(\mathrm{g} \mathrm{d}^{-1}\right)$ & 42.08 & 44.80 & 0.80 & 4.51 & 0.04 \\
\hline Fecal $\left(\mathrm{g} \mathrm{d}^{-1}\right)$ & 4.39 & 7.25 & 0.36 & 15.30 & 0.00 \\
\hline Fecal/Ingested $\left(\mathrm{g} \mathrm{g}^{-1}\right)$ & 0.10 & 0.16 & 0.00 & 12.76 & 0.00 \\
\hline Absorbed $\left(\mathrm{g} \mathrm{d}^{-1}\right)$ & 37.69 & 37.54 & 0.63 & 4.12 & 0.87 \\
\hline Absorbed/ingested $\left(\mathrm{g} \mathrm{g}^{-1}\right)$ & 0.90 & 0.84 & 0.01 & 1.95 & 0.00 \\
\hline Urinary $\left(\mathrm{g} \mathrm{d}^{-1}\right)$ & 17.14 & 16.50 & 0.76 & 11.05 & 0.56 \\
\hline Urinary/ingested $\left(\mathrm{g} \mathrm{g}^{-1}\right)$ & 0.41 & 0.37 & 1.42 & 8.95 & 0.08 \\
\hline Urinary/absorbed $\left(\mathrm{g} \mathrm{g}^{-1}\right)$ & 0.45 & 0.44 & 0.02 & 8.50 & 0.50 \\
\hline Retained $\left(\mathrm{g} \mathrm{d}^{-1}\right)$ & 20.55 & 21.04 & 0.50 & 5.87 & 0.50 \\
\hline Retained/ingested $\left(\mathrm{g} \mathrm{g}^{-1}\right)$ & 0.49 & 0.47 & 0.01 & 6.46 & 0.32 \\
\hline Retained/absorbed $\left(\mathrm{g} \mathrm{g}^{-1}\right)$ & 0.55 & 0.56 & 0.02 & 6.90 & 0.50 \\
\hline
\end{tabular}

SH, diet with $6 \%$ of soybean hulls inclusion; SEM, Standard error of means; CV, Coefficient of variation; PROB, Probability; NDF, Neutral detergent fiber.

used in the diet, contribution of AA present in fibrous feedstuffs may be overestimated.

Increase in NRET in the WB treatment served as an indicator that the basal diet was limited in AA and that at least a portion of the AA added through this feedstuff were used for protein retention. The NRET:NABS ratio demonstrated that the efficiency with which NABS was used for nitrogen retention was similar between treatments, suggesting that the inclusion of WB at practical levels did not reduce body protein synthesis due to a possible increase in the synthesis of endogenous proteins.

\section{Trial 2 - Soybean Hulls}

The highest NFEC observed in the pigs that received the $\mathrm{SH}$ diet can be attributed to the high NDF content of this ingredient $(61 \%)$. It is known that fiber increases the ileal nutrient flow (ZERVAS \& ZIJLSTRA, 2002), which results in higher amounts of nitrogenous compounds in the intestine, increasing microbial activity in this compartment and; consequently, the NFEC (DÉGEN et al., 2011). The presence of a relatively high amount of fiber-bound $\mathrm{N}$ in $\mathrm{SH}$, a component that has low digestibility, is also a factor that may have contributed to the higher amount of NFEC in the animals fed with the SH diet (BINDELLE et al., 2008).

The difference in NFEC: NING ratio was $6 \%$, which was closer to that obtained by ZERVAS \& ZIJLSTRA (2002), comparing diets with inclusion of $15 \%$ SH replacing wheat and soybean meal. It is noteworthy that the $\mathrm{SH}$ contribution to digestible $\mathrm{N}$ was zero. This means that the relative amount of $\mathrm{N}$ added by the SH was fully recovered in feces.

Results obtained for NABS and their ratio with NING (NABS:NING) corroborate the previous argument. Despite the extra $\mathrm{N}$ added through $\mathrm{SH}$, the $\mathrm{N}$ absorption was similar between treatments resulting in a lower NABS: NING (Table 3) for these animals, this means lower absorption efficiency of the $\mathrm{N}$ ingested for SH treatment. Similar results were deduced by DILGER et al. (2004); although, ZERVAS \& ZIJLSTRA (2002) observed a contribution to the digestible $\mathrm{N}$ from this feedstuff. 
Conversely, the NURI and NURI:NABS ratio can be interpreted as indicative that the metabolic demands were not, at least in significant amounts, capable of causing an imbalance in the AA profile that was available for protein synthesis. The same interpretation applies when analyzing NRET and its ratio with NABS (NRET:NABS).

Studies have shown that the NDF increases specific endogenous losses of $\mathrm{AA}$ and $\mathrm{N}$ in amounts that can vary from 0.5 to $1.5 \mathrm{~g} \mathrm{~kg}^{-1} \mathrm{DMI}$ (SCHULZE et al., 1994). Therefore, it is possible to admit that some of the AA absorbed and used for body protein deposition will be diverted to endogenous protein synthesis. As the ideal profiles of AA for maintenance and deposition are different (VAN MILGEN \& DOURMAD, 2015), an imbalance in the standard AA profile is expected to occur, which induces an increase of NURI and a possible decrease in NRET. In addition, the metabolic cost of this synthesis could decrease the utilization efficiency of NING.

\section{CONCLUSION}

The inclusion of practical levels of wheat bran and soybean hulls does not significantly affect the metabolic costs involved with nitrogen metabolism. However, only wheat bran was able to contribute to the $\mathrm{N}$ balance of pigs, while the relative amount of $\mathrm{N}$ added by $\mathrm{SH}$ was recovered fully in feces.

\section{DECLARATION OF CONFLICT OF INTERESTS}

The authors declare no conflict of interest. The founding sponsors had no role in the design of the study; in the collection, analyses, or interpretation of data; in the writing of the manuscript, and in the decision to publish the results.

\section{ETHICS AND BIOSSECURITY COMMITTEE APPROVAL}

The experimental protocol was reviewed and approved by the Ethics Committee in Animal Experimentation of the Universidade Federal de Santa Maria (opinion n ${ }^{\circ}$ 8073200815).

\section{ACKNOWLEDGEMENTS}

The authors are grateful to Conselho Nacional de Desenvolvimento Científico e Tecnológico (CNPq), and Coordenação de Aperfeiçoamento de Pessoal de Nível Superior (CAPES) (finance code 001) for scientific, financial support and student's scholarships.

\section{AUTHORS' CONTRIBUTIONS}

The authors contributed equally to the manuscript.

\section{REFERENCES}

AOAC INTERNATIONAL. Official Methods of Analysis of AOAC International. 16 ed. Arlington, 1995. Available from: $<$ https://doi.org/aoac.methods.90.15.x >. Accessed: Jul. 18, 2018. doi: aoac.methods.90.15.x.

BINDELLE, J. et al. Nutritional and environmental consequences of dietary fibre in pig nutrition: a review. Biotechnology, Agronomy, Society and Environment, v.12, n.1, p.69-80, 2008. Available from: <http://www.pressesagro.be/base/text/v12n1/69. pdf $>$. Accessed: Mar. 15, 2019.

BLANK, B. etal. Effect of dietary fibre on nitrogen retention and fibre associated threonine losses in growing pigs. Archives of Animal Nutrition, v.66, n.1, p.86-101, 2012. Available from: <https:// tandfonline.com/doi/full/10.1080/1745039X.2012.663669>. Accessed: Jul. 22, 2018. doi: 10.1080/1745039X.2012.663669.

DÉGEN, L. et al. Dietary impact of NDF from different sources on the apparent ileal digestibility of amino acids. Acta Agraria Kaposvári ensis, v.15, n.1, p.1-11, 2011. Available from: <http:// journal.ke.hu/index.php/aak/article/view/2022/2544>. Accessed: Jul. 25, 2018

DILGER, R.N. et al. Digestibility of nitrogen and amino acids in soybean meal with added soyhulls. Journal of Animal Science, v.82, n.5, p.715-724, 2004. Available from: $<$ https://academic.oup. com/jas/article-abstract/82/3/715/4835281?redirectedFrom=fullte xt>. Accessed: Jul. 23, 2018. doi: 10.2527/2004.823715x.

HANSEN, M.J. et al. Influence of different fibre sources in diets for growing pigs on chemical composition of faeces and slurry and ammonia emission from slurry. Animal Feed Science and Technology, v.184, n.3-4, p.326-336, 2007. Available from: $<$ https:// www.sciencedirect.com/science/article/pii/S0377840106003427>. Accessed: Jul. 14, 2018. doi: 10.1016/j.anifeedsci.2006.08.021.

HUANG, Q. et al. Effects of inclusion levels of wheat bran and body weight on ileal and fecal digestibility in growing pigs. Asian-Australasian Journal of Animal Science, v.28, n.6, p.847-854, 2015. Available from: <https://www.ncbi.nlm.nih.gov/pmc/articles/PMC4 412981/pdf/ajas-28-6-847.pdf $>$. Accessed: Jul. 23, 2018. doi: 10.5713/ajas.14.0769.

JHA, R.; BERROCOSO, J.F.D. Dietary fiber and protein fermentation in the intestine of swine and their interactive effects on gut health and on the environment: A review. Animal Feed Science and Technology, v.212, n.1, p.18-26, 2016. Available from: $\quad<\mathrm{https}: / / \mathrm{www}$.sciencedirect.com/science/article/pii/ S0377840115300766>. Accessed: Jul. 13, 2018. doi: 10.1016/j. anifeedsci.2015.12.002.

LE GOFF, G.G. et al. Influence of dietary fiber on digestive utilization and rate of passage in growing pigs, finishing pigs and adult sows. Animal, v.74, n.3, p.503-515, jun. 2002. Available from: <https://doi.org/10.1017/S1357729800052668>. Accessed: Jul. 03, 2018. doi: 10.1017/S1357729800052668.

LIBAO-MERCADO, A.J. et al. True ileal amino acid digestibility and endogenous ileal amino acid losses in growing pigs fed wheat shorts- or casein-based diets, Journal of Animal Science, v.84, n.6, p.1351-1361, 2006. Available from: $<$ https://academic.oup. com/jas/article-abstract/84/6/1351/4776622>. Accessed: Mar. 15, 2019. doi: $10.2527 / 2006.8461351 x$. 
LIU, Z. et al. Effects of dietary cellulose levels on the estimation of endogenous amino acid losses and amino acid digestibility for growing pigs. Animal Nutrition, v.2, n.2, p.74-78, 2016. Available from: <https://www.sciencedirect.com/science/article/ pii/S2405654516300464>. Accessed: Jul. 10, 2018. doi: 10.1016/j. aninu.2016.04.001.

METZLER, B. U.; MOSENTHIN, R. A review of interactions between dietary fiber and the gastrointestinal microbiota and their consequences on intestinal phosphorus metabolism in growing pigs. Asian-Australasian Journal of Animal Sciences, v.21, n.4, p.603-615, 2008. Available from: <http://www.ajas.info/ journal/view.php?number $=21822>$. Accessed: Mar. 15, 2019. doi: 10.5713/ajas.2008.r.03.

NATIONAL RESEARCH COUNCIL (Washington, Estados Unidos). Nutrient requirements of swine, 11 ed. Washington: National Academy, 2012, 400 p.

NOBLET, J. Net energy evaluation of feeds and determination of net energy requirements for pigs Revista Brasileira de Zootecnia, v.36, suppl. p.277-284. Available from: <http://www.scielo.br/pdf/rbz/ v36s0/25.pdf 10.1590/S1516-35982007001000025>. Accessed: Mar. 15, 2019. doi: 10.1590/S1516-35982007001000025.

ROSTAGNO, H.S. et al 3. ed. Brazilian table for poultry and swine: Food composition and nutrient requirements. Federal University of Viçosa, MG, Brazil. 2011. 252p.

PASCOAL, L.A.F. et al. Purified cellulose, soybean hulls and citrus pulp as a source of fiber for weaned piglets. Scientia Agricola, v.72, n.5, p.400-410, 2015. Available from: <http://www.scielo.br/ scielo.php?script $=$ sci arttext\&pid $=\mathrm{S} 0103-90162015000500400>$. Accessed: Mar. 15, 2019. doi: 10.1590/0103-9016-2014-0210.

SAUVANT, D. et al. Tables of composition and nutritional value of feed materials. Wageningen Academic Publishers, The Netherlands. 2004. 304p.

SCHULZE, H. et al. Effect of level of dietary neutral detergent fiber on ileal apparent digestibility and ileal nitrogen losses in pigs. Journal of Animal Science, v.72, n.9, p.2362-2368, 1994. Available from: <https:/www.ncbi.nlm.nih.gov/ pubmed/8002455>. Accessed: Jul. 19, 2018. doi: 1994.7292362x.

STEIN, H.H. Procedures for determining digestibility of amino acids, lipids, starch, fibre, phosphorus, and calcium in feed ingredients fed to pigs. Animal Production Science, v.57, n.11, p.2317-2324, 2017. Available from: <http://www.publish.csiro.au/ AN/AN17343>. Accessed: Jul. 10, 2018. doi: 10.1071/AN17343.

VAN MILGEN, J.; DOURMAD, J.Y. Concept and application of ideal protein for pigs. Journal of Animal Science and Biotechnology, v.6, n.1, p.1-15, 2015. Available from: <https:// jasbsci.biomedcentral.com/articles/10.1186/s40104-015-0016-1>. Accessed: Jul. 10, 2018. doi: 10.1186/s40104-015-0016-1.

VAN SOEST, P.J. Development of a comprehensive system of feed analysis and its application to forage. Journal of Animal Science, v.26, n.1, p.119-120, 1967. Available from: <www. animalsciencepublications.org/publications/jas/abstracts/26/1/ JAN0260010119>. Accessed: Jul. 13, 2018. doi: 10.2527/ jas1967.261119x.

WILFART, A. et al. Sites of nutrient digestion in growing pigs: Effect of dietary fiber. Journal of Animal Science, v.85, n.4, p.976-983, 2007. Available from: <https://academic.oup.com/jas/ article-abstract/85/4/976/4788850>. Accessed: Jul. 18, 2018. doi: 10.2527/jas.2006-431.

ZERVAS, S.; ZIJLSTRA, R.T. Effects of dietary protein and fermentable fiber on nitrogen excretion patterns and plasma urea in grower pigs. Journal of Animal Science, v.80, n.12, p.32473256, 2002. Available from: <https://academic.oup.com/jas/ article-abstract/80/12/3247/4789604>. Accessed: Jul. 12, 2018. doi: $10.2527 / 2002.80123247 x$.

ZHANG, W. et al. The effects of dietary fiber level on nutrient digestibility in growing pigs. Journal of Animal Science and Biotechnology, v.4, n.1, p.1-7, 2013. Available from: <https:// jasbsci.biomedcentral.com/articles/10.1186/2049-1891-4-17>. Accessed: Jul. 11, 2018. doi: 10.1186/2049-1891-4-17. 